\title{
Evaluation of Anti-Microbial Activity and Proximate Composition of Alkaloids from Vitex doniana Seed
}

\author{
Theophilus K. Udeani ${ }^{1}$, Linus 0. Ugwu ${ }^{1,2}$, Charles 0. Nnadi $^{3}$ \\ and Chukwugozie N. Okwuosa ${ }^{1}$
}

\author{
${ }^{1}$ Department of Medical Laboratory Sciences, Faculty of Health Sciences \&Technology College of Medicine, \\ University of Nigeria Enugu Campus, Nigeria \\ ${ }^{2}$ Department of Veterinary Medicine, Faculty of Veterinary Medicine, University of Nigeria Nsukka, Nigeria \\ ${ }^{3}$ Department of Pharmaceutical and Medicinal Chemistry, Faculty of Pharmaceutical Sciences, \\ University of Nigeria Nsukka, Nigeria
}

(Received: November 12, 2020; Accepted: May 22, 2021; Published (web): June 20, 2021)

\begin{abstract}
The study investigated the in vitro anti-microbial activity of crude alkaloids from the seeds of Vitex doniana against some selected bacteria and fungal strains. Agar well diffusion method was used to test the antimicrobial activity using ciprofloxacin and ketoconazole as controls. Phytochemical and proximate analyses were carried out by standard methods. The crude extract showed the presence of alkaloids, tannins and resins in abundance. Proximate analysis indicated fat/oil $(11 \pm 0.73 \%)$, protein $(0.26 \pm 0.02 \%)$, moisture $(0.21 \pm 0.01 \%)$, ash $(5.0 \pm 0.22 \%)$ and carbohydrate $(6.42 \pm 0.28 \%)$. The antimicrobial study indicated that the crude extract was more effective against Pseudomonas aeruginosa (MIC $3.84 \mathrm{mg} / \mathrm{ml}$ ) and Salmonella typhi (MIC $3.84 \mathrm{mg} / \mathrm{ml}$ ) and other Gram-positive bacteria. The crude alkaloids generally showed lower activity in case of Gram-negative (MIC Salmonella typhi $4.20 \mathrm{mg} / \mathrm{ml}$ ) than in Gram-positive bacteria (MIC Staphylococcus aureus $2.52 \mathrm{mg} / \mathrm{ml}$ ). Surprisingly, the crude alkaloids from the seeds, in addition to improved activity against all the bacteria strains, showed significant activity against Candida albicans (MIC $1.18 \mathrm{mg} / \mathrm{mL}$. V. doniana seed extract was found to be potent against some clinical strains of both Gram-positive and negative bacteria but not fungi; however, its alkaloids has promising antifungal activity.
\end{abstract}

Key words: Vitex doniana seed, proximate, anti-microbial, alkaloids, phytochemicals

\section{INTRODUCTION}

Phytochemicals derived from plants have shown great potential in the treatment of intractable infectious diseases including opportunistic infections. ${ }^{1}$ Certain medicinal plants containing protoberberine and related alkaloids, picralima type indole alkaloids and garcinia of flavanones used in the traditional African system of medicine, have also been found to be active against a wide variety of microorganisms. ${ }^{1}$ In the management of diseases, plant materials are known to be present in more than $50 \%$ of western drugs, have provided defense against pathogens or template for synthetic drugs. ${ }^{2,3}$ Vitex

Correspondence to: Charles O. Nnadi

Tel. No.: +2348064947734

E-mail: charles.nnadi@unn.edu.ng

Dhaka Univ. J. Pharm. Sci. 20(1): 81-86, 2021 (June)

DOI: https://doi.org/10.3329/dujps.v20i1.54035 doniana (Verbenaceae), commonly called black plum, is a savanna plant species in wooded grasslands and can also be found along forest edges. ${ }^{4}$ The seeds appear singly and traditionally, fresh fruits cannot be stored for long periods. $V$. doniana is used in the treatment of conjunctivitis, skin rashes due to measles, chickenpox, respiratory infections and abdominal disorder and diarrhea. ${ }^{5-7}$ Its antioxidant and anti-microbial activities against the methicillinresistant Staphylococcus aureus (MRSA), vancomycin-resistant Enterococcus (VRE) and multidrug-resistant Burkholderia cepacia and Pseudomonas aeruginosa are known. ${ }^{8,9}$ Several other activities of the stem bark, leaves and fruits of black plum have been documented, however, the enormous phytochemical constituents in $V$. doniana are still underutilized. ${ }^{10-12}$ Available data, to the best of our knowledge, showed that the seeds of $V$. 
doniana is underutilized in folk medicine due to scanty information about its ethnopharmacological relevance, phytochemical and nutritional composition as well as proximate content. To further understand the relevance of this plant in folk medicine, the present study investigated the phytochemical and proximate compositions and then evaluated the antimicrobial activity of the extract and alkaloidal constituents of $V$. doniana seeds.

\section{MATERIALS AND METHODS}

Plant material. Ripe $V$. doniana seeds were collected from Nike forest Enugu, Nigeria and identified and authenticated by Mr. Alfred Ozioko at the Department of Plant Science and Biotechnology, University of Nigeria Nsukka. A voucher specimen (UNH 356a) was prepared and stored at the herbarium of the Institute. The seeds were washed thoroughly with distilled water and allowed to dry at room temperature. The dried seeds were pulverized into coarse material.

Extraction. The coarsely pulverized seeds (500 g) was macerated in $(1 \mathrm{~L})$ of methanol for $48 \mathrm{~h}$ with intermittent agitation. The mixture was filtered and the filtrate was allowed to evaporated in-vacuo. The extract $(18.8 \mathrm{~g})$ was stored in an airtight container and left at $-4^{\circ} \mathrm{C}$ until used.

Extraction of alkaloids. An aliquot (5 g) of the extract was dissolved in methanol-water $(1: 9,500$ $\mathrm{ml})$. It was then rendered alkaline ( $\mathrm{pH} 12)$ with $1 \%$ $\mathrm{v} / \mathrm{v}$ of $\mathrm{NH}_{4} \mathrm{OH}$ solution. The mixture was successively partitioned with dichloromethane $(3 \mathrm{x}$ $500 \mathrm{ml}$ ) in a separatory funnel as previously described. ${ }^{13}$ The combined dichloromethane soluble extract were evaporated in a rotary thin-film evaporator to obtain the crude alkaloid. The presence of alkaloid-rich extract was confirmed by colour intensity in dragendorff reagent.

Test microorganisms. The test microorganisms were cultures of Staphylococcus aureus, Pseudomonas aeruginosa, Bacillus subtilis, Enterococcus faecalis, Salmonella typhi, Candida albicans and Aspergillus nigger. They were all of the wild type strains. These were obtained from the
Microbiology Unit, Department of Pharmaceutical Microbiology and Biotechnology of the University of Nigeria Nsukka.

Growth media. Molten Meuller Hilton agar (MHA), saboroud dextrose agar (SDA), mannitol salt agar (MSA), nutrient agar and nutrient broth used were prepared according to the manufacturers' directives after which the planted media were tested for sterility at a temperature of $30^{\circ} \mathrm{C}$.

Preparation and standardization of inocula. The test microorganisms were sub-cultured from nutrient agar slants into the sterile nutrient broth. They were incubated at $37^{\circ} \mathrm{C}$ for $18 \mathrm{~h}$. Using $4 \mathrm{ml}$ of sterile normal saline, each of the test organisms was standardized to 0.5 McFarland's turbidity standard which is equivalent to $1.5 \times 10^{8} \mathrm{cfu} / \mathrm{ml}$. This was used in the seeding of organisms on the plates.

Sensitivity test of microorganisms. The sensitivity of test microorganisms to the extract and alkaloids of $V$. doniana was determined using the agar well diffusion methods. ${ }^{14}$ A $100 \mathrm{mg}$ of extract was solubilized in $1 \mathrm{ml}$ of dimethyl sulphoxide (DMSO). Sterile petri dishes containing $25 \mathrm{ml}$ of solidified MHA and SDA media were appropriately labeled with the test isolates. Each plate was seeded with the corresponding standardized test organism. Using a sterile $6 \mathrm{~mm}$ cork borer, five (5) wells were bored in the seeded plates and $100 \mu \mathrm{L}$ of each of the five concentrations (100.0, 50.0, 25.0, 12.5, and 6.25 $\mathrm{mg} / \mathrm{ml}$ ) of the extract was introduced (dropwise) into the respective wells. The plates were left for 20 minutes to allow for diffusion of extracts before they were incubated at $37^{\circ} \mathrm{C}$ for $24 \mathrm{~h}$ for bacteria and $25^{\circ} \mathrm{C}$ for $48 \mathrm{~h}$ for fungi. Then the inhibition zone diameters (IZD) of the test strains sensitive to the extracts were measured. Similar procedures were carried out using standard drugs (ciprofloxacin and ketoconazole) at concentration (10-0.3125 mg/ml), alkaloids (50-1.5625 $\mathrm{mg} / \mathrm{ml})$ and dimethyl sulphoxide $(100 \mu \mathrm{l})$ in place of the plant crude extract.

Determination of minimum inhibitory concentration (MIC). The MICs of the crude 
extract, alkaloids and the control agents determined using the agar well diffusion method were obtained by a plot of the logarithm of the concentration of the extracts/controls against the squared IZD $\left(\mathrm{mm}^{2}\right)$. The antilogarithm of the intercept (I) on the log concentration-axis was used to calculate the MICs. ${ }^{14}$

Phytochemical analysis of the extract. The qualitative phytochemical composition of the extract was determined using standard methods. ${ }^{1,8}$

Proximate analysis. The proximate analysis was carried on the different seed harvested at various time intervals to determine the effect of time of harvest on the nutrient composition of seeds. The harvested seeds were air-dried in the greenhouse for 21 days, ground into a powder and stored in an airtight container till the required analysis. Proximate composition of seeds was carried out to determine the ash content, total carbohydrate, crude protein content, crude fat content, crude fiber and moisture content. The analysis was carried out using the standard method of the Association of Official Analytical Chemist. ${ }^{15}$

\section{RESULTS and DISCUSSION}

The results of the phytochemical analysis showed the presence of secondary metabolites. The crude extract showed the presence of alkaloids, tannins and resins in high concentration (Table 1). The carbohydrates, reducing sugar, flavonoids, proteins, oil and terpenoids were found in medium concentration while glycosides, saponins, steroids and acidic compounds were observed in relatively smaller concentration. The proximate studies indicated the presence of fat/oil, protein, moisture, carbohydrate and ash with a high percentage of fat and oil. Fibre was, however, absent in the extract (Table 2) and the proximate composition was found to be independent of season or time of collection.

Table 1. Phytochemical components of $V$. doniana extract.

\begin{tabular}{llc}
\hline S/No & Phytochemicals & Relative abundance \\
\hline 1 & Carbohydrates & ++ \\
2 & Reducing sugars & ++ \\
3 & Alkaloids & +++ \\
4 & Saponins & + \\
5 & Tannins & +++ \\
6 & Flavonoids & ++ \\
7 & Oil & ++ \\
8 & Terpenoids & ++ \\
9 & Glycosides & + \\
10 & Steroids & + \\
11 & Acidic compounds & + \\
\hline
\end{tabular}

+ Low, ++ Medium, +++ High

Table 2. Proximate composition of $V$. doniana seed.

\begin{tabular}{llllllll}
\hline & Protein & Fibre & Moisture & Ash & Fat/oil & $\begin{array}{l}\text { Soluble } \\
\text { sugar }\end{array}$ & Carbohydrate \\
\hline aVD & $0.26 \pm 0.02$ & 0.00 & $0.21 \pm 0.01$ & $5.00 \pm 0.22$ & $11.0 \pm 0.73$ & $6.42 \pm 0.28$ & $\mathrm{Nd}$ \\
bVDr & 7.28 & 6.73 & 48.77 & 5.70 & 3.0 & $\mathrm{Nd}$ & 28.95 \\
cVDr & $0.85 \pm 0.09$ & $11.48 \pm 0.55$ & $39.42 \pm 0.72$ & $3.41 \pm 0.09$ & $2.44 \pm 0.06$ & $13.55 \pm 0.49$ & $29.57 \pm 0.67$ \\
cVDw & $2.32 \pm 0.22$ & $11.82 \pm 0.25$ & $38.16 \pm 0.71$ & $3.63 \pm 0.08$ & $2.46 \pm 0.09$ & $9.88 \pm 0.12$ & $31.71 \pm 0.81$ \\
cVKr & $0.87 \pm 0.05$ & $10.42 \pm 0.47$ & $40.56 \pm 0.77$ & $3.40 \pm 0.13$ & $2.35 \pm 0.06$ & $14.45 \pm 0.50$ & $28.04 \pm 0.56$ \\
cVKw & $2.24 \pm 0.28$ & $10.35 \pm 0.33$ & $40.86 \pm 0.39$ & $3.34 \pm 0.41$ & $2.07 \pm 0.10$ & $10.44 \pm 0.61$ & $31.56 \pm 0.55$ \\
cVFr & $0.98 \pm 0.06$ & $12.38 \pm 0.43$ & $37.74 \pm 0.76$ & $3.66 \pm 0.26$ & $2.66 \pm 0.09$ & $15.39 \pm 0.44$ & $27.28 \pm 0.35$ \\
cVFw & $2.78 \pm 0.22$ & $12.39 \pm 0.53$ & $38.46 \pm 0.92$ & $3.31 \pm 0,52$ & $2.35 \pm 0.09$ & $9.53 \pm 0.07$ & $31.30 \pm 0.40$ \\
dVDr & $8.24 \pm 0.24$ & $0.58 \pm 0.08$ & $16.66 \pm 1.06$ & $11.5 \pm 1.1$ & $34.62 \pm 0.56$ & $\mathrm{Nd}$ & $28.4 \pm 1.06$ \\
eVPvl & 13.73 & 28 & 16.85 & 8.00 & 7.00 & $\mathrm{Nd}$ & 26.43 \\
fVNl & 16.94 & 33.18 & 16.95 & 9.37 & 1.8 & $\mathrm{Nd}$ & 21.76 \\
gVN1 & $12.2-15.2$ & $25.5-30.5$ & $15-18.7$ & $7.5-8.5$ & $5.0-9.0$ & $\mathrm{Nd}$ & $7.5-10.57$ \\
hVN1 & $0.87 \pm 0.01$ & $11.61 \pm 0.14$ & $53.45 \pm 0.15$ & $8.07 \pm 0.17$ & $7.05 \pm 0.03$ & $\mathrm{Nd}$ & $18.95 \pm 0.05$ \\
iVD1 & 8.75 & 15.58 & 8.04 & 7.92 & 5.10 & $\mathrm{Nd}$ & 70.20 \\
jVPl & $3.4 \pm 0.07$ & $60 \pm 0.4$ & $240 \pm 20$ & $5.3 \pm 1.0$ & $0.44 \pm 0.05$ & $\mathrm{Nd}$ & $30 \pm 0.3$ \\
\hline
\end{tabular}

VD (V. doniana), VK (V. kiniensis), VF (V. fischerii), VPv (V. parviflora), VN (V. negundo), VP (V. payos) a(this study), $\mathrm{b}^{12}, \mathrm{c}^{16}, \mathrm{~d}^{17}, \mathrm{e}^{18}$, $\mathrm{f}^{19}, \mathrm{~g}^{20}, \mathrm{~h}^{21}, \mathrm{i}^{22}, \mathrm{j}^{23}, \mathrm{r}$ (ripe fruits), $\mathrm{w}$ (raw fruits), $\mathrm{Nd}$ (no data). L (leaves). Values are expressed as mean $\pm \mathrm{SD}$ (an $=3$, others $=$ not stated). 
The results of the susceptibility test of the extract and alkaloids of $V$. doniana are shown in Table 3 . The extracts, at varying concentrations, inhibited the growth of B. subtilis, S. aureus, E. faecalis, $P$. aeruginosa and $S$. typhi. The extract has no activity against the strains of $C$. albicans and A. niger. The alkaloids showed improved activity against all the bacteria tested and $C$. albicans. The minimum inhibitory concentrations (MICs) of the crude extract and standard drugs against some clinical strains are shown in Table 4 which was obtained from the graphs of log concentration of extract/drugs against squared IZD. The MIC values indicated that both the extract and alkaloids were less active against all the microorganisms tested compared to standard drugs. The order of sensitivity of the microorganisms to the extract and alkaloids showed that B. subtilis and $S$. typhi were respectively the least active while no activity was observed against $A$. niger in both cases.

Table 3. Susceptibility test of extract and alkaloids of $V$. doniana.

\begin{tabular}{|c|c|c|c|c|c|c|c|c|c|c|c|c|c|c|c|c|c|c|}
\hline \multirow{2}{*}{$\begin{array}{l}\text { Microorganism } \\
\text { / IZD (mm) }\end{array}$} & \multicolumn{6}{|c|}{ Extract $(\mathrm{mg} / \mathrm{ml})$} & \multicolumn{6}{|c|}{ Alkaloids (mg/ml) } & \multicolumn{6}{|c|}{ Controls (mg/ml) } \\
\hline & 100 & 50 & 25 & $\begin{array}{l}12 . \\
5\end{array}$ & $\begin{array}{l}6.2 \\
5\end{array}$ & $\begin{array}{l}3.1 \\
3\end{array}$ & 50 & 25 & 12.5 & 6.25 & $\begin{array}{l}3.1 \\
3\end{array}$ & 1.56 & 10.0 & 5.0 & 2.5 & 1.25 & 0.63 & 0.31 \\
\hline B. subtilis & 17.7 & 7.7 & 7.0 & 6.0 & 6.0 & 6.0 & 16.5 & 12.4 & 10.2 & 9.0 & 8.5 & 7.8 & 36.3 & 30.3 & 28.0 & 26.3 & 22.3 & 17.3 \\
\hline S. aureus & 16.0 & 9.0 & 8.3 & 7.7 & 6.6 & 6.0 & 14.4 & 10.0 & 9.0 & 8.4 & 7.2 & 6.0 & 32.7 & 28.0 & 23.7 & 20.0 & 6.0 & 6.0 \\
\hline E. faecalis & 21.3 & 17 & 12.3 & 6.0 & 6.0 & 6.0 & 14.0 & 11.0 & 9.8 & 9.2 & 7.8 & 6.2 & 28.0 & 24.0 & 21.7 & 19.3 & 16.0 & 6.0 \\
\hline P. aeruginosa & 10.6 & 8.3 & 7.7 & 7.3 & 6.0 & 6.0 & 18.4 & 14.4 & 12.0 & 11.0 & 8.0 & 7.5 & 36.3 & 31.0 & 26.3 & 21.0 & 6.0 & 6.0 \\
\hline S. typhi & 10.6 & 8.3 & 7.7 & 7.3 & 6.0 & 6.0 & 25.3 & 11.0 & 10.0 & 9.5 & 8.0 & 6.5 & 26.0 & 23.0 & 17.7 & 15.3 & 6.0 & 6.0 \\
\hline C. albicans & 6.0 & 6.0 & 6.0 & 6.0 & 6.0 & 6.0 & 10.8 & 8.3 & 7.0 & 6.0 & 6.0 & 6.0 & 36.7 & 31.0 & 26.3 & 23.0 & 19.0 & 16.3 \\
\hline A. niger & 6.0 & 6.0 & 6.0 & 6.0 & 6.0 & 6.0 & 6.0 & 6.0 & 6.0 & 6.0 & 6.0 & 6.0 & 22.7 & 19.7 & 18.7 & 17.3 & 14.0 & 12.0 \\
\hline
\end{tabular}

IZD of 6.0 means no inhibition; IZD $(\mathrm{mm})$ includes the diameter of hole borer $(6 \mathrm{~mm})$; ciprofloxacin and ketoconazole served as standards for antibacterial and antifungal tests, respectively.

Table 4. MIC of extract and alkaloids of $V$. doniana against some microorganisms.

\begin{tabular}{lllllll}
\hline \multirow{2}{*}{ Microorganism } & \multicolumn{3}{c}{ Extract } & \multicolumn{2}{c}{ Crude alkaloids } & \multicolumn{2}{c}{ Controls } \\
\cline { 2 - 7 } & Log I & MIC $(\mathrm{mg} / \mathrm{ml})$ & Log I & MIC $(\mathrm{mg} / \mathrm{ml})$ & Log I & MIC $(\mathrm{mg} / \mathrm{ml})$ \\
\hline B. subtilis & 1.4495 & 28.15 & 0.1641 & 1.46 & -0.9245 & 0.12 \\
S. aureus & 0.9493 & 8.90 & 0.4476 & 2.52 & -0.4000 & 0.40 \\
E. faecalis & 1.1073 & 12.80 & 0.0226 & 1.05 & -0.6467 & 0.22 \\
P. aeruginosa & 0.5841 & 3.84 & 0.1693 & 1.48 & -0.3936 & 0.40 \\
S. typhi & 0.5841 & 3.84 & 0.6228 & 4.20 & -0.3976 & 0.40 \\
C. albicans & - & - & 0.0723 & 1.18 & -0.6903 & 0.20 \\
A. niger & - & - & - & - & -1.0578 & 0.09 \\
\hline
\end{tabular}

$\log \mathrm{I}=\mathrm{c}$ from the regression $\mathrm{y}=\mathrm{mx}+\mathrm{c}$ of $\log$ concentration against IZD ${ }^{2}$ of Table 3 (Figures not shown for brevity).

Susceptibility tests are used to describe the array of microorganisms in which particular agents can inhibit their growth, reduce their virulence, or eliminate from the host system. The extracts of $V$. doniana inhibited the growth of both Gram-positive and Gram-negative bacteria as shown by their various zones of inhibition diameters (IZDs) and MICs.
However, the extract could not inhibit the growth of fungi used in our study. This showed a broad spectrum of activity against bacterial pathogens which was concentration-dependent. The alkaloids, however, showed a surprisingly strong activity against $C$. albicans. 
The minimum inhibition concentration of the extract against bacteria showed varied activities which were lowest against $B$. subtilis and highest against both $S$. typhi and $P$. aeruginosa. The alkaloids showed broad spectrum of activity against Gramnegative and Gram-positive pathogens as well as $C$. albicans. The slight differences in the antimicrobial activity of the $V$. doniana alkaloids against Gramnegative and positive bacteria could be explained based on differences in the structural architect of bacteria. Gram-positive bacteria possess a thicker peptidoglycan layer and lipoteichoic acid barrier unlike Gram-negative which have thin peptidoglycan with an outer membrane containing liposaccharides acting as endotoxins. ${ }^{24}$ The lipoteichoic acid, acting as exotoxins to invading agents, could have neutralized the alkaloids which are basic thus reducing the antimicrobial activities. The thick peptidoglycan layer could also block penetration thereby making resistance to physical disruption by external agents higher. ${ }^{25}$ The high activity of the extract against S. typhi (a gastrointestinal pathogen) also supports the use of the fruit and seed as food in Africa. Previous studies had demonstrated the antimicrobial activities of alkaloids of plant origin, in some cases, the antimicrobial activity was attributed to Vitex species. $^{26,27}$ These phytochemical constituents of plants are known to exhibit medicinal activity as well as physiological activity. ${ }^{27}$ The improved activity in crude alkaloids could be attributed to the presence of inhibiting or complexing substances present in the extract which probably were removed during alkaloid extraction.

The results obtained from the proximate analysis of $V$. doniana established that it can be ranked as oilrich seeds due to their relatively high oil content when compared with the other components of the seeds. The low moisture content of the seeds would hinder the growth of micro-organisms and the storage life would be high. ${ }^{28}$ The proximate content of the seeds did not compare favourably with other species of Vitex, however, its consumption as food could be implicated in certain cardiovascular disorders such as atherosclerosis, cancer and aging because a diet providing 1-2 \% of its caloric of energy from fat is said to be sufficient to human. ${ }^{16-23,29}$ The crude fibre content of zero $(0.0 \%)$ for the seeds cannot be compared to other Vitex species that could be beneficial in some disease conditions such as obesity, diabetes, cancer and gastrointestinal disorders. ${ }^{12,30}$ The variation in composition, even within the same morphological parts of the same Vitex species could be attributed to the geographical location of the plants.

\section{CONCLUSION}

$V$. doniana seed extract proved to be potent against some Gram-positive and negative microorganisms and $C$. albicans but not A. niger. Most importantly, the susceptibility patterns of the tested microorganisms showed the presence of broadspectrum antimicrobial agents. This research has shown that the seed, seldom used in herbal practices, has medicinal properties when consumed as food due to its proximate and phytochemical composition.

\section{DECLARATION}

We (authors) declare that the work described in this manuscript was carried out by us and the contents of the paper have not been published before or submitted elsewhere for publication. Theophils Udeani and Chigozie Okwuosa developed the concept and supervised the research. Linus Ugwu conducted the benchwork. Charles Nnadi collected and analyzed the data. All the authors were involved in the preparation of the manuscript for publication.

\section{REFERENCES}

1. Obonga, W.O., Nnadi, C.O., Chima, C.C., Okafor, S.N. and Omeje, E.O. 2019. In-vitro antioxidant and in-vivo antiinflammatory potential of Marantochloa leucantha (Marantaceae) extracts and fractions. Dhaka Univ. J. Pharm. Sci. 18, 233-40.

2. Nnadi, C.O., Okorie, H.N., Nwodo, N.J. 2021. Evaluation of in vitro antiprotozoal and cytotoxic activities of selected Medicinal Plants used in Nigerian Folk Medicine. Trop. J. Nat. Prod. Res. 5, 609-612.

3. Nnadi, C.O., Udeani, T.K.C., Ugwu, L.O. 2016. Woundhealing and antimicrobial properties of dichloromethane fraction of Dialium guineense (Wild) fruit coat. Res. Pharm. Sci. 11, 219-226. 
4. Suleiman, M.M. and Yusuf, S. 2008. Antidiarrheal activity of the fruits of Vitex doniana in laboratory animals. Pharm. Biol. 46, 387-92.

5. Ladeji, O., Udoh, F.V. and Okoye, Z.S.C. 2004. Activity of aqueous extract of the bark of Vitex doniana on uterine muscle response to drugs. Phytother. Res. 19, 804-806.

6. James, D.B., Owolabi, A.O., Bisalla, M. and Jassium, H. 2010. Effects of aqueous extracts (leaves and stem) of Vitex doniana on carbon tetrachloride-induced liver injury in rats. British J. Pharmacol. Toxicol. 1, 1-5.

7. Agunu, A.Y., Andrew, G., Zezi, A. and Abdurahim, E.M. 2005. Evaluation of five medicinal plants used in diarrhea treatment in Nigeria. J. Ethnopharmacol. 101, 27-30.

8. Obonga, W.O., Nnadi, C.O., Agbo, M.O., Kenechukwu, F.C. and Nwodo, U. 2014. Distribution of methicillin-resistant Staphylococcus aureus (MRSA) in an apparently healthy population and its susceptibility to saponins from Dialium guineense. Brit. J. Pharm. Res. 4, 2200-2209

9. Orhana, I., Özçelik, B., Karaoglu, T. and Sener, B. 2007. Antiviral and antimicrobial profiles of selected isoquinoline alkaloids from Fumaria and Corydalis species. Z Naturforsch, C, J Biosci. 62, 19-26.

10. Kilani, A.M. 2006. Antibacterial assessment of whole stem bark of Vitex doniana against some Enterobacteriaceae. Afr. J. Biotechnol. 5, 958-959.

11. Adejumo, A.A., Alaye, S.A., Ajagbe, R.O., Abi, E.A. and Adedokun, F.T. 2013. Nuitritional and anti-nutritional composition of black-plum (Vitex doniana). J. Natur. Sci. Res. 3, 144-148.

12. Agbede, J.O. and Ibitoye, A.A. 2007. Chemical composition of black plum (Vitex doniana): An underutilized fruit. $J$. Food Agric. Environ. 5, 95-96.

13. Nnadi, C.O., Nwodo, N.J., Kaiser, M., Brun, R., Schmidt, T.J. 2017. Steroid alkaloids from Holarrhena africana with strong activity against Trypanosoma brucei rhodesiense. Molecules. 22, 1129.

14. Rath, C.C., Dash, S.K. and Mishra, R.K. 2002. Antimicrobial efficacy of six Indian essential oils individually and in combination. J. Essential Oil Bearing Plants. 5, 99-107.

15. Association of Official Analytical Chemist (AOAC). 1990. Official Methods of Analysis. Association of Official Analytical Chemists, 15th Ed, Washington D.C.

16. Ochieng, C.O. and Nandwa, B.O. 2010. Proximate composition, phenolic content and antioxidant activities of three black plum (Vitex sp.) fruits: preliminary results. $J$. Food Technol. 8, 118-125.

17. Vunchi, M.A., Umar, A.N., King, M.A., Liman, A.A., Jeremiah, G. and Aigbe, C.O. 2011. Proximate, vitamins and mineral composition of Vitex doniana (black plum) fruit pulp. Nig. J. Basic Appl. Sci. 19, 97-101.

18. Panti, A.B., Aguda, R.M., Razal, R.A., Belina-Aldemita, M.D. and Tongco, J.V.V. 2014. Proximate analysis, phytochemical screening and total phenolic and flavonoid content of the ethanolic extract of molave Vitex parviflora Juss. leaves. J. Chem Pharma. Res. 6, 1538-1542.
19. Ullah, Z., Ullah, R., Shah, A.H.A., Ahmad, I. and Haider, S 2012. Phytochemical and biological evaluation of Vitex negundo Linn: A Review. Int. J. Pharm. Pharma. Sci. 3, 2421-1431

20. Gautam, L.N., Shrestha, S.L., Wagle, P. and Tamrakar, B.M. 2008. Chemical constituents from Vitex negundo Linn of Nepalese origin. Scientific World. 6, 27-32.

21. Salleh, R.M., Dashti, N.G. and Thong, O.M. 2014. Proximate analysis and anti-proliferative properties of Vitex negundo $\mathrm{L}$. Sains Malaysiana. 43, 1543-1547.

22. Bello, M.O., Asubonteng, K., Sodamade, A. and Adeniyi, S. 2014. Nutrient potentials of two lesser known leafy vegetables (Vitex doniana L.and Sesamum indicum L.). Int. Food Res. J. 21, 1993-1999.

23. Kimondo, J.M., Agea, J.G., Okia, C.A., Abohassan, R.A.A., Nghitoolwa, Ndeunyema, E.T.N., Woiso, D.A., Teklehaimanot, Z. and Mulatya, J. 2012. Physiochemical and nutritional characterization of Vitex payos (Lour.) Merr. (Verbenaceae): An indigenous fruit tree of Eastern Africa. $J$. Horticul. Fores. 4, 161-168.

24. Alvarez, L.,Cordier, B., van Teeffelen, S., Cava F. 2020. Analysis of Gram-negative bacteria peptidoglycan by ultraperformance liquid chromatography. Bio-Protocol. 10, e3780-e3780

25. Gupta, R.S. 2011. Origin of diderm (gram-negative) bacteria: antibiotic selection pressure rather than endosymbiosis likely led to the evolution of bacterial cells with two membranes. Antonie Van Leeuwenhoek. 100, 171-182.

26. Goncalves, J.L., Leitao, S.G., Manache, F.D., Miranda, M.M., Santos, M.G., Romanos, M.T. and Wigg, M.D. 2001. In vitro antiviral effect of flavonoid rich extracts of Vitex polygama (Verbenaceae) against acyclovir-resistant herpes simplex virus type 1. Phytomed. 8, 477-480.

27. Hossain, N.M., Paul, N., Sohrab, M.H., Rahman, E. and Rashid, M.A. 2001. Antimicrobial activity of Vitex trifolia. Fitoter. 72, 695-697.

28. Deng, L.Z., Tao, Y., Mujumdar, A.S., Pan, Z., Chen, C., Yang, X.H., Liu, Z.L., Wang, H., Xiao, H.W. 2020. Recent advances in non-thermal decontamination technologies for microorganisms and mycotoxins in low-moisture foods. Trends in Food Sci. Technol. 106, 104-112.

29. Antia, B.S., Akpan, E.J., Okon, P.A. and Umoren, I.U. 2006. Nutritive and anti-nutritive evaluation of sweet potatoes (Ipomoea batatas) leaves. Pak. J. Nutr. 5, 166-168.

30. Cai, Y., Folkerts, J., Maurer, M., Braber, S. 2020 Microbiota-dependent and -independent effects of dietary fibre on human health. Brit. J. Pharmacol. 177, 1363-1381. 